\title{
СУДЕБНЫЙ КОНТРОЛЬ ЗА ЗАКОННОСТЬЮ \\ И ОБОСНОВАННОСТЬЮ ПРИМЕНЕНИЯ МЕР ПРЕСЕЧЕНИЯ В ОТНОШЕНИИ НЕСОВЕРШЕННОЛЕТНИХ ПОДОЗРЕВАЕМЫХ, ОБВИНЯЕМЫХ
}

\author{
И. С. Тройнина \\ Воронежский институт МВД России \\ Поступила в редакцию 18 января 2021 г.
}

\begin{abstract}
Аннотация: статья посвящена расслотрению вопросов судебного контроля за законностью и обоснованностью задержания, а также избрания и применения мер пресечения несовершеннолетнил подозреваелыл, обвиняельлм. Анализируется судебная практика приленения мер пресечения в отношении несовершеннолетних.

Ключевые слова: несовершеннолетние подозреваелье (обвиняелье), суд, судебный контроль, леры пресечения, права и законные интересы несовершеннолетних подозреваельх (обвиняельх), долашний арест, заключение под стражу, содержание под стражей.
\end{abstract}

\begin{abstract}
: the article is devoted to the consideration of issues of judicial control over the legality and validity of detention, as well as the election and application of preventive measures for juvenile suspects and accused. The article analyzes the judicial practice of applying preventive measures against minors.

Key words: juvenile suspects (accused), court, judicial control, preventive measures, rights and legal interests of juvenile suspects (accused), house arrest, detention, detention.
\end{abstract}

На стадии предварительного расследования должностные лица, ведущие производство по уголовному делу, при наличии оснований существенно ограничивают конституционные права и интересы граждан путем применения мер процессуального принуждения, а также избрания мер пресечения. В практической деятельности не исключены случаи, что действия, ограничивающие права и интересы личности, имеют незаконный и необоснованный характер. Поэтому в целях недопущения нарушения предусмотренных законодательством прав граждан со стороны следственных органов особое место занимает процессуальный контроль со стороны суда как одного из основных гарантов прав личности.

Важную роль в обеспечении прав и законных интересов играет судебный контроль за применением задержания и мер пресечения в отношении не только взрослых подозреваемых, обвиняемых, но и несовершеннолетних. Следует согласиться с мнением авторов, считающих, что судебный контроль в досудебном производстве представляет собой самостоятельное направление уголовно-процессуальной деятельности, назначение которой заключается в обеспечении законности, защите прав

(C) Тройнина И. С., 2021 


\section{Вестник ВГУ. Серия: Право}

и свобод участников уголовного процесса, способствовании достижению общего назначения уголовного судопроизводства ${ }^{1}$.

Применение процессуального принуждения вообще и мер пресечения в частности имеет своей целью обеспечение порядка уголовного судопроизводства и предотвращение неправомерных действий подозреваемого либо обвиняемого, представляющих угрозу для правосудия, для решения задач уголовного судопроизводства ${ }^{2}$.

В соответствии с Европейской конвенцией о защите прав человека $\left(\right.$ ст. 5) ${ }^{3}$, а также Конституцией РФ применение мер принуждения и мер пресечения, существенно ущемляющих права личности, должно быть произведено только на основании судебного решения. Уголовно-процессуальный кодекс РФ к мерам пресечения, избираемым по решению суда, относит: домашний арест, заключение под стражу, запрет определенных действий, залог. Следует отметить, что продление срока задержания свыше 48 часов допускается также только по судебному решению.

Не случайно Верховный Суд РФ уделяет много внимания этому вопросу в своих постановлениях. В частности, имеются в виду постановления Пленума Верховного Суда РФ «О практике применения судами законодательства о мерах пресечения в виде заключения под стражу, домашнего ареста, залога и запрета определенных действий» ${ }^{4}$; «О судебной практике применения законодательства, регламентирующего особенности уголовной ответственности и наказания несовершеннолетних» ${ }^{5}$.

В частности, в постановлении Пленума Верховного Суда РФ «О судебной практике применения законодательства, регламентирующего особенности уголовной ответственности и наказания несовершеннолетних» отмечается, что суды в основном правильно применяют уголовное и уголовно-процессуальное законодательство, общепризнанные принципы и нормы международного права, международные договоры Российской Федерации при рассмотрении уголовных дел и материалов в отношении несовершеннолетних, совершивших преступления, обеспечивая защиту их прав и законных интересов при осуществлении правосудия. Исследуя полномочия и роль суда в уголовном судопроизводстве Российской Федерации, можно сделать вывод о том, что именно суд является основным ор-

$248{ }^{1}$ См.: Рыгалова K. А. Судебный контроль как самостоятельная уголовно-процессуальная фонкция // Вестник СПб. ун-та МВД России. 2017. № 1 (73). С. 99.

${ }^{2}$ См.: Стародубова Г. В. Избрание меры пресечения в отношении подозреваемого или обвиняемого : объективная основа и субъективная оценка // Рос. юстиция. 2017. № 12 .

${ }^{3}$ См.: Права человека : сборник междунар. документов. М., 1998. С. 68.

${ }^{4} \mathrm{O}$ практике применения судами законодательства о мерах пресечения в виде заключения под стражу, домашнего ареста, залога и запрета определенных действий : постановление Пленума Верховного Суда РФ от 19 декабря 2013 г. № 41 (в ред. от 11.06.2020). Доступ из справ.-правовой системы «КонсультантПлюс».

${ }^{5}$ О судебной практике применения законодательства, регламентирующего особенности уголовной ответственности и наказания несовершеннолетних : постановление Пленума Верховного Суда РФ от 1 ноября 2011 г. № 1 (в ред. от 29.11.2016). Доступ из справ.-правовой системы «КонсультантПлюс». 
ганом, констатирующим законность и обоснованность задержания либо избрания мер пресечения к несовершеннолетним подозреваемым, обвиняемым. Попутно отметим, что именно по инициативе суда происходит избрание более мягкой меры пресечения по сравнению с той, необходимость которой обосновывалась в ходатайстве об избрании меры пресечения следователями либо дознавателями.

На официальном сайте Воронежского областного суда опубликована справка по результатам изучения практики рассмотрения судами ходатайств об избрании и продлении меры пресечения. Данный обзор подготовлен с целью обеспечения правильного и единообразного применения судами Воронежской области действующего законодательства при рассмотрении ходатайств органов предварительного следствия об избрании и продлении меры пресечения.

Так, согласно статистическим данным за 2019 г. судами Воронежской области рассмотрено 1589 ходатайств органов предварительного расследования об избрании меры пресечения в виде заключения под стражу, что на 171 ходатайство меньше, чем за 2018 г.

Из рассмотренных в 2019 г. ходатайств удовлетворено 1296, или 81,5 \%. Для сравнения: в 2018 г. было удовлетворено 1395 ходатайств, или 79,2 \%. Таким образом, при снижении числа обращений с ходатайствами об избрании меры пресечения в виде заключения под стражу увеличилась доля удовлетворенных ходатайств.

Такие ходатайства рассматривались по преступлениям, относящимся к категории особо тяжких - 349; тяжких - 775; средней тяжести - 389 и небольшой тяжести - 76.

Удовлетворено ходатайств по преступлениям, относящимся к категориям особо тяжких - 318; тяжких - 587; средней тяжести - 326; небольшой тяжести - 65. В отношении несовершеннолетних рассмотрено - 9, из них 3 - удовлетворено.

Ходатайств о продлении срока содержания под стражей судами области в 2019 г. рассмотрено - 2863, что на 15 ходатайств меньше, чем в 2018 г., из которых удовлетворено - 2779 (97,6 \%), отказано в 84 случаях. Для сравнения: в 2018 г. было удовлетворено 2803 ходатайства, или $97,3 \%$.

Удовлетворено ходатайств о продлении срока содержания под стражей по преступлениям, относящимся к категориям особо тяжких - 1065; тяжких - 1150; средней тяжести - 472; небольшой тяжести - 92.

В отношении несовершеннолетних -13 , из них удовлетворено $-5^{6}$.

Исходя из анализа представленных судами материалов можно сделать вывод, что одной из основных причин отказа в удовлетворении ходатайств следователей является недостаточность представленных дан-

${ }^{6}$ Воронежский областной суд - «Справка по результатам изучения практики рассмотрения судами ходатайств об избрании и продлении меры пресечения». URL: http://oblsud.vrn.sudrf.ru/modules.php?name=docum_sud\&id=489 (дата обращения: 27.11.2020). 
ных, которые подтверждают необходимость избрания и применения меры пресечения в виде заключения под стражу. Также причиной отказа в удовлетворении ходатайства органов предварительного расследования об избрании и применении меры пресечения в виде заключения под стражу возможно отнести обоснованное постановление судьи о том, что надлежащее производство по уголовному делу может быть обеспечено при избрании и применении подозреваемому, обвиняемому более мягкой меры пресечения, а именно залога, домашнего ареста или запрета определенных действий.

Принципиально важным является вывод Пленума Верховного Суда РФ «О судебной практике применения законодательства, регламентирующего особенности уголовной ответственности и наказания несовершеннолетних» о том, что уголовные дела в отношении несовершеннолетних в судах как первой, так и второй инстанции должны рассматриваться наиболее опытными судьями (п. 4). Однако следовало бы в указанном пункте более четко обозначить критерии, по которым судья признается опытным, когда речь идет о судебном контроле за задержанием и заключением под стражу несовершеннолетних. Думается, обоснованным было бы отнесение к данным критериям стажа работы в качестве судьи не менее пяти лет и прохождение специальной подготовки по вопросам педагогики, социологии, подростковой психологии, криминологии, виктимологии, применения ювенальных технологий, используемых в рамках процессуального закона.

В ходе судебного контроля за применением задержания и мер пресечения в отношении несовершеннолетних подозреваемых, обвиняемых, как следует из упомянутых постановлений Пленума Верховного Суда РФ, необходимо осуществлять проверку:

- обоснованности изложенных в ходатайстве органов предварительного следствия о применении в отношении несовершеннолетнего подозреваемого или обвиняемого меры пресечения в виде заключения под стражу положений о необходимости заключения несовершеннолетнего под стражу;

- наличия правовых и фактических оснований принятия решения о применении в отношении несовершеннолетнего подозреваемого или обвиняемого меры пресечения в виде заключения под стражу;

- обоснованности изложенных в ходатайстве органов предварительного следствия о применении в отношении несовершеннолетнего подозреваемого или обвиняемого меры пресечения в виде заключения под стражу положений о невозможности применения иной, более мягкой меры пресечения;

- требований ч. 1 и 2 ст. 108 УПК РФ и ч. 6 ст. 88 УК РФ о том, что избрание меры пресечения в виде заключения под стражу не допускается в отношении несовершеннолетнего, не достигшего 16 лет, который подозревается или обвиняется в совершении преступлений небольшой или средней степени тяжести впервые, а также в отношении остальных 
несовершеннолетних, совершивших преступления небольшой тяжести впервые;

- обеспечения в ходе задержания и избрания меры пресечения права на защиту несовершеннолетнего подозреваемого, обвиняемого, а также права на дополнительные процессуальные гарантии, предусмотренные для несовершеннолетних УПК РФ.

К сожалению, на практике рассматриваемые обстоятельства не всегда учитываются. Так, «Обзор практики рассмотрения судами ходатайств об избрании меры пресечения в виде заключения под стражу и о продлении срока содержания под стражей» указывает на то, что судами не всегда с достаточной полнотой исследовались основания, подтверждающие применения такой меры пресечения, как заключение под стражу, суды не выполняли требования ст. 99 УПК РФ, согласно которым, кроме тяжести совершенного преступления должны учитываться сведения о личности подозреваемого или обвиняемого, возраст и состояние здоровья, семейное положение, род занятий и другие обстоятельства ${ }^{7}$ Исходя из этого, можно сказать, что не в полной мере судами выполняются требования, возложенные уголовно-процессуальным законодательством при избрании меры пресечения.

\section{Библиографический список}

Рыгалова K. А. Судебный контроль как самостоятельная уголовно-процессуальная фрункция // Вестник Санкт-Петербургского ун-та МВД России. 2017. № 1 (73). C. 98-101.

Стародубова Г. В. Избрание меры пресечения в отношении подозреваемого или обвиняемого : объективная основа и субъективная оценка // Российская юстиция. 2017. № 12. С. 62-64

\section{References}

Rygalova $K$. A. Judicial control as an independent criminal procedure function // Bulletin of the St. Petersburg University of the Ministry of Internal Affairs of Russia. 2017. № 1 (73). P. 98-101.

Starodubova G. V. Electing a preventive measure against a suspect or accused: an objective basis and a subjective assessment // Russian Justice. 2017. № 12 . P. 62-64.

7 Обзор практики рассмотрения судами ходатайств об избрании меры пресечения в виде заключения под стражу и о продлении срока содержания под стражей : утвержден Президиумом Верховного Суда РФ 18 января 2017.

Воронежский институт МВД России

Тройнина И. С., кандидат юридических наук, старший преподаватель кабедры уголовного процесса

E-mail: i.troynina@mail.ru
Voronezh Institute of the Russian Ministry of Internal Affairs

Troynina I. S., Candidate of Legal Sciences, Senior Lecturer of the Criminal Process Department

E-mail: i.troynina@mail.ru 